\title{
KOCSIS Zsófia
}

\section{A duális képzés eredményességre gyakorolt hatása}

\section{Bevezetés}

A kilencvenes évek információs és technológiai fejlődése, valamint az expanzió kihívásai új feladatok elé állították az egyetemeket. A felsőoktatási intézményeknek nemcsak akadémiai, elméleti tudást, hanem a gyakorlati ismeretek átadását is meg kell valósítani. Ehhez elengedhetetlen, hogy az egyetemek tisztában legyenek a munkaerőpiac igényeivel, $\mathrm{s}$ az akadémiai szerepük mellett gazdasági szerepet is betöltsenek (Teichler, 2003). A felsőoktatás bolognai folyamatként elhíresült szerkezetváltása során is eminens cél volt, hogy az alapképzések gyakorlatorientált, a munkaerőpiacon azonnal beváltható végzettséget nyújtsanak. A diplomások felé támasztott követelmények leginkább a munkaerőpiac folyamatos változásai, a nemzetközivé válás folyamata, és a globalizáció miatt következtek be. Véleménye szerint a munkaadók elvárják, hogy a diplomások a saját szakterületükön szakértőkké váljanak, és rugalmasak legyenek (Teichler, 2011). A gazdasági rendszer gyors fejlődése megköveteli, hogy a munkaerőpiacra belépők megfelelő tudással, szakértelemmel és képességekkel rendelkezzenek, s ehhez szükséges az oktatási intézmények és a munkaerőpiac együttműködése (Kivinen \& Nurmi, 2003).

A gazdasági életet és ezzel együtt a munkaerő-piaci folyamatokat érintő változásokkal is magyarázható, hogy az egyetemisták elkezdtek munkát vállalni a tanulmányaik során, eltérő okokból ugyan, de bekapcsolódnak a munkaerő-piaci folyamatokba. A friss diplomásoknak biztosítaniuk karrierjüket az egyre nagyobb kihívást jelentő globális munkaerőpiacon (Donald et al., 2018). A felsőoktatásból a munkaerőpiacra való belépés fontos időszak a fiatalok életében (Grosemans et al., 2017), az átmenet az egyén életének különböző szakaszaiban fordul elő, amelyeket egyértelműen bizonyos események jeleznek, mint a diploma megszerzése, a foglalkoztatás megkezdése (Heinz, 2009) A pályakezdést már nem tudjuk egyszeri, lezárt folyamatnak tekinteni, ugyanis a hallgatói és dolgozó státusz folyamatosan váltakozik az átmenet időszakában. A legtöbb fiatal gyakran változtatja a státusukat, s mivel a hallgatói munkavállalás növekvő tendenciája miatt az sem kizárt, hogy a hallgatói és dolgozó státusz párhuzamosan jelenik meg a felsőoktatási évek alatt (ECLAC, 2017; Sági, 2010). A fiatalok esetében gyakori, hogy ez a folyamat egybeesik egy másik életfázisra való átmenettel, amely bizonytalanságot szül, és a jövő kialakításának garantált, biztonságos útja (Vysotskaya, 2017). Az átmenet során az oktatás stabilitása elmarad, amelyet egy bizonytalan, de dinamikus időszak vált fel. Ez a bizonytalanság a globalizálódó, gyorsan változó munkaerőpiac miatt keletkezett, ahol a technológiai innovációkhoz, újításokhoz kell a pályakezdőknek igazodni, és folyamatosan a tudásuk, képességeik frissítésére kell törekedniük (Grosemans et al., 2017), mindemellett nemcsak a változó körülményekkel kell megbirkózniuk, hanem kellőképpen ki kell használniuk az új helyzeteket (Teichler, 2011).

A tanulásból a munka világába való átmenet, a munkaerőpiacban végbemenő változások követése, kezelése és a változásokhoz való alkalmazkodás egyaránt időt igényel a hallgatóktól, az oktatási intézménytől (Derényi, 2010), az átmenet folyamatában komoly jelentőséggel bírnak a korábbi munkatapasztalatok, a megszerzett képzettség, valamint az oktatási háttér és a munka illeszkedése (Grosemans et al., 2017).

\section{Megváltozott elvárások}

A felsőoktatás feladata többek között a munkára való felkészítés, így az intézményeknek tisztában kell lennie a munkaerőpiac elvárásaival (Castro \& Levy, 2001). A CHEERS kutatásban a végzettek munkaerőpiaci sikerességére összpontosítottak, objektív és szubjektív mutatók által mérték fel a végzettek elégedettségét, a munka presztízsét és az illeszkedés mértékét (Teichler, 2002). Teichler 
(2011) REFLEX kutatása arra hívja fel a figyelmet, hogy a képzés jellemzői, a tanítási módok nem feltétlenül jelentik azt, hogy a felsőoktatás elegendő alapot szolgáltat a munkaerőpiacra való belépéshez, és nem feltétlenül biztosítja a később karrier eredményességét. A válaszadók csaknem ötöde szerint a képzési program nem adott megfelelő alapot a munka megkezdéséhez, nem alapozta meg a munkafeladatok megfelelő elvégzését, és nem nyújtott használható alapot a jövőbeli tanuláshoz és karrierépítéshez (Teichler, 2011). A diplomások foglalkoztathatóságának problémái olyan tényezőkből erednek, mint az egyetemek és a munkaerőpiac, illetve a vállalatok közötti gyenge vagy rossz múködésű kommunikációs csatornák, az egyetemek és vállalatok közötti együttműködés mennyiségi és minőségi hiánya (Rostan \& Stan, 2017).

A 21. században előtérbe került a kompetenciák fejlesztésének igénye, az oktatók, politikai döntéshozók és munkaadók is egyre nagyobb hangsúlyt fektetnek a megfelelő kompetenciák kialakítására. A szakmákon belüli feladatok tartalmai egyre nagyobb változásokon mennek át, s egyre nagyobb növekedésnek indult a nem kognitív képességeket igénylő feladatok fontossága és aránya (Fazekas, 2018). Autor et al. (2003) az amerikai munkaerőpiac vizsgálata során elsőként világított rá arra, hogy folyamatosan növekedett azoknak a feladatoknak az aránya, amelyek legfóképpen szociális készségeket és nem kognitív képességeket igényelnek. Deming (2017) kutatása szerint a nem kognitív képességek iránti igény növekedése arra vezethető vissza, hogy a digitális eszközök és számítógépek továbbra is gyengék az emberi interakció szimulációjában, valamint a társadalmi környezet ismertében. Munkahelyi interakció a csapatmunka, egymás támogatása és a munkatársakhoz való rugalmas alkalmazkodás. Míg az OECD elemzései az alábbi készségeket nem kognitív vagy szociálisérzelmi készségeknek nevezi, addig Heckman et al (2016) gyakran használják a puha készségek (soft skills) kifejezést. Fazekas (2018) szerint a nem kognitív képességek, amelyek a másokkal való sikeres együttmúködés feltétele, valamint a munkaerő-piaci változásokhoz való alkalmazkodás lényeges tényezői. Khine \& Areepattamannil (2016) kutatása arra mutatott rá, hogy a munka alapú tanulás hozzájárul a nem kognitív képességek fejlesztéséhez, hiszen a tapasztalok, a munkahelyi környezetben való részvétel, a munkatársakkal folytatott kommunikáció mind-mind a fejlődés eleme. Pogántsnik (2019a) szerint az oktatási rendszerek többsége a végzetteket olyan kognitív képességekkel látja el, amelyek a munka világába való belépéshez szükségesek. Míg az olyan nem kognitív tényezők, mint a kritikus gondolkodás, kommunikációs készségek, együttmúködés, lehetővé teszik, hogy a végzettek potenciális munkaerővé váljanak.

\section{Duális képzés jelentősége}

Napjainkban a munkaerőpiac olyan elvárásokat állít a munkavállalók elé, amelyek elsajátítása nem mindig történik meg a hagyományos oktatás keretei között. Szabó (1998) kutatásából kiderül, hogy a hallgatók gyakran úgy érzékelik, hogy egy állásinterjú során az egyetemi, főiskolai végzettség kevésbé számít, inkább olyan kompetenciákat tartanak fontosnak, amelyeknek az oktatása nem része az egyetemi óráknak. A megkérdezett cégek az alkalmazható nyelvtudással rendelkezőket tartja megfelelő munkavállalónak, így a szaknyelv tanítása egy nagyon fontos feladata lenne az egyetemnek. Emellett a cégekkel való együttmúködés fontos eleme lenne, hogy az egyetem részesítse a hallgatókat olyan felkészítésben, amelyek során elsajátíthatják, hogyan múködhetnek hatékonyan, ha csoportban dolgoznak. (Szabó, 1998). Az intézményen kívüli alternatívák, a szakmai gyakorlatok megoldást jelenthetnek a különböző készségek fejlesztésére. Az egyik ilyen megoldás lehet a duális képzés (Pogátsnik, 2018). A duális képzés során a hallgatók olyan elméleti és gyakorlati ismereteket szerezhetnek, amelyekre a felsőoktatási intézmény falain belül nem lenne lehetőségük. A gyakorlati ismeretek megszerzéséhez a duális képzés nagymértékben hozzájárul. 2014-ben vezették be a magyar felsőoktatási intézményekben a német tapasztalatokon alapuló duális képzést, amelynek legfőbb jellegzetessége, hogy az elméleti oktatásra az egyetem keretein belül kerül sor, míg a gyakorlati oktatás egy vállalatnál valósul meg (Pogátsnik, 2018). A duális képzésben részt vevő hallgatók a hagyományos képzésben lévő társaikhoz hasonlóan félévente 14 hétig teljesítik az adott szemeszter tanulmányi követelményeit, majd ezt követően vesznek részt a gyakorlati képzésen, amely télen 8, nyáron 16 hétig tart (Pogátsnik, 2018). A duális képzésben lévő hallgatók a gyakorlati időszakot egy olyan vállalatnál 
töltik, amellyel a felsőoktatási intézmény szerződést kötött, s a munkaszerződés által a hallgatók a munkájukért díjazást kapnak (Kocsis, 2018). A duális képzés teljesítményelvű és projektfeladatközpontú képzés, melyben az elméleti ismeretanyag, a vállalati munkavégzés során azonnal eredménytermelő tényezővé válik (Zimányi, 2016; 98). A duális képzés célja, hogy a hallgatók a különböző analitikus, szintetizáló, kategorizáló tudásukat a munkafolyamatokban eredményesen tudják alkalmazni és adaptálni. A partnervállalatok mentorainak segítségével, és az ő visszajelzéseik által az ismeretek elsajátításának hatásfoka növelhető, amely készségszintű és mély tudás kialakulását segíti elő (Setényi, 2011). A képzésben összeállított tudatos és célirányos feladatok hozzáadott értéket képviselnek mind akadémiai, mind vállalati szempontból, hiszen a feladatok elvégzése során olyan eredmények születhetnek (szakdolgozat, termék, applikáció stb.), amely növelheti a cégek versenyképességét. A probléma-alapú és projekt-alapú tanulás előtérbe helyezése hozzájárul olyan stratégiai törekvések megvalósulásához, mint az Európai Unió vagy hazánk tudásalapú gazdaságának megteremtése (Zimányi, 2016). A projekt-alapú munka révén fejlődik a hallgatók önálló munkavégzése, soft skilljeik és megismerkedhetnek a vállalati kultúrával (Kovács \& Török, 2016). A duális képzésben részt vevő hallgatóknak nemcsak a gyakorlati képzés során, hanem az egyetemi tanulmányaik terén is eredményesnek kell lenniük. A kutatásunk során igyekszünk választ kapni arra kérdésre, hogyan befolyásolja a hallgatók eredményességét a duális képzés? Valóban hozzáadott értéknek minősül?

Korábbi kutatási eredmények szerint a megszerzett szakmai kompetenciák, az elmélet gyakorlatban való felhasználása, a duális képzésben kialakított tanterv és a vállalati környezet révén a duális képzésben részt vevő hallgatók a végzettsége megszerzése után potenciális munkaerővé válnak (Pogátsnik, 2018; Simonics, 2015). A duális képzés során elsajátított informális tudás növeli a szakmai teljesítményt. Az ismeretek elsajátítása, a szakértővé válás folyamata során meghatározó szerepe van a mentorokkal, és tapasztaltabb kollégákkal való együttműködésnek, és közös projekteknek. Az alábbi tényezők a készségek- különösen a problémamegoldás, együttműködés, nem kognitív képességekpozitív fejlődéséhez vezetnek (Pogátsnik, 2018). Burns \& Chopra (idézi Pogátsnik, 2019a) szerint az órákon megtanult elméletek, módszerek gyakorlatban való alkalmazása, a kialakított kapcsolati háló referenciaként szolgálhat a jövőbeli foglalkoztatás során. Kiss (2016) kutatásában az álláskeresés időszakát, a horizontális illeszkedést befolyásoló tényezőket vizsgálta, s eredményei arra mutattak rá, hogy a munkaadók preferálják a képzési többletet, mint a külföldi munkatapasztalat vagy szakmai munkatapasztalat, ugyanis ezek egyfajta jelzésként szolgálhatnak a munkaadónak, amely magasabb termelékenységet feltételez.

A duális képzés mindhárom fél számára előnyös lehet. A hallgatók lehetőséget kapnak, hogy gyakorlati ismeretekre tegyenek szert, valamint a gyakorlati képzés révén plusz jövedelemhez jutnak. A képzésben való részvétel azonban motivációt, és bizonyos fokú érettséget igényel a hallgatótól, hogy megfelelően tudjanak teljesíteni, és sikeresen tudják összehangolni a munkát és a tanulmányaikat. A partnervállalatok számára a duális képzés munkaerőt biztosít, míg az egyetem a gazdaság különböző résztvevőivel múködhet együtt, s bővítheti a vállalt feladatinak körét (Pogátsnik, 2019a).

\section{A kutatás módszere}

A téma aktualitása a tanulmányok melletti munkavégzés növekvő szerepében, illetve a munkaerőpiac és a felsőoktatás összehangolásának problémakörében gyökerezik. Vizsgálatunk célja, hogy az egyetemek visszacsatolást kapjanak a duális képzés eredményességéről, és a gyakorlati képzés színvonaláról. A duális képzést olyan értelmezési keretben vizsgáljuk, hogy milyen módon támogatja a hallgatók egyetemi pályafutását, és eredményességét. Kutatásunk során kvantitatív és kvalitatív módszereket alkalmaztunk: duális és nem duális képzésben részt vevő hallgatók körében végeztünk kérdőíves felmérést $(n=291)$. A kérdőív kérdésblokkjai a duális képzés minél szélesebb körü megismerésére irányultak. Továbbá félig strukturált interjúkat készítettünk egyetemistákkal $(n=20)$, oktatókkal $(n=4)$ és a partnercégek munkatársaival $(n=11)$. A kutatás során azt vizsgáltuk, hogy a duális képzés hogyan hat a hallgatók eredményességére és fejlődésére. A kutatás során megvizsgáltuk az 
eredményesség általunk használt objektív mutatóit (féléves tanulmányi átlag, nyelvvizsga, tudományos munka, saját alkotás stb.) a duális és nem duális hallgatók körében. Hipotézisünk szerint a duális hallgatók eredményesebbek a tanulmányaik során, $s$ a képzés révén kimondottan a puha készségeik fejlődnek. Feltételezéseinket azzal indokoljuk, hogy az egyetemi és a munkahelyi oktatás különböző társadalmi környezetet, és eltérő tapasztalatokat kínál a hallgatók számára (Pogátsnik, 2019a), továbbá a hallgatók munkavégzésének identitásképző szerepe van, hiszen növeli a tanulmányok végzésével kapcsolatos elköteleződést, erősíti az önszabályozó képességet, valamint pozitív hatással van a tanulmányi és későbbi munkaerő-piaci teljesítményre (Perna, 2010).

\section{Hallgatók körében végzett kvantitatív kutatás eredményei}

A jelenlegi vizsgálat során a hallgatók eredményességére fókuszáltunk, amely magába foglalja az egyetemen illetve a gyakorlati helyen tanúsított teljesítményüket. A kvantitatív kutatás eredményeit kiegészítettük az interjúalanyok tapasztalataival.

A megkérdezett hallgatók 44\%-a duális képzésben tanul, fóként a honlapok és az oktatóik révén tájékozódtak a duális képzés nyújtotta lehetőségéről. Török (2017) kutatása szerint a duális képzésre jelentkező hallgatók erősen motiváltak, s kimondottan fontos számukra, hogy a munkaerőpiac elvárásaihoz illeszkedő végzettséget szerezzenek. Korábbi kutatási eredményekhez hasonlóan (Pogátsnik, 2018; Zimányi, 2016) a duális képzésben lévő hallgatók több mint felét a szakmai tapasztalatszerzés és a képzés időben való befejezése motiválta. A szakmai célok mellett a jövedelemszerzés is jelentős szerepet játszott.

1. ábra: A hallgatók rövid távú céljai ( $\mathrm{N}=171)$

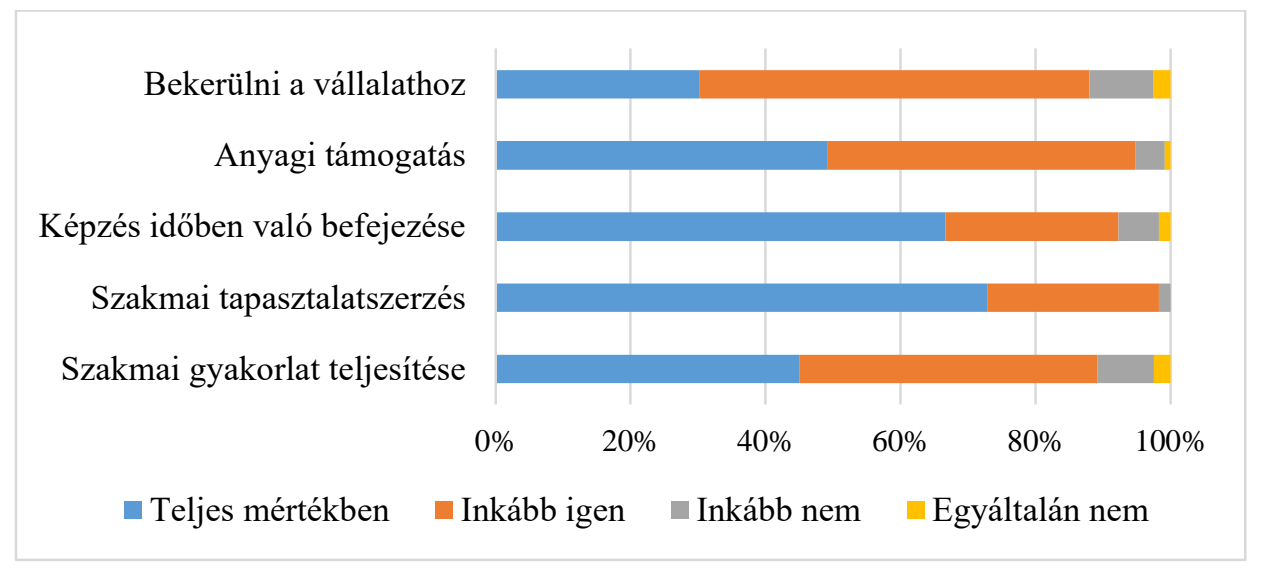

Forrás: saját szerkesztés

A hallgatók hosszú távú céljaikat tekintve elmondható, hogy azért választották az említett képzési formát, mert professzionális szakmai tapasztalatra szeretnének szert tenni, és jól fizető állást találni. A válaszadók 39\%-nak a legfóbb célja, hogy a végzettség megszerzése után lehetősége legyen, hogy a különböző állások között válogasson, míg 35\%-nak a gyakorlati helyén szeretne elhelyezkedni.

A hallgatók eredményességét a szubjektív véleményeik, illetve a tanulmányi átlaguk és az egyéb eredményeik alapján vizsgáltuk. Az eredményesség fogalmát két oldalról is megközelíthetjük. Egyrészt az eredményesség lehet a különböző képességek, attitűdök jelenléte, ám a normatív előírások soraiban nem túnik fel a munkavállalással kapcsolatos elköteleződés, a munkába állás szándéka. Másrészt beszélhetünk eredményességről akkor is, ha negatív irányból közelítjük meg a fogalom meghatározását, mint a bukások száma, a lemorzsolódás vagy a tanulmányaikból való kiábrándulás. (Pusztai, 2013). A hallgatók sikerességét mérhetjük objektív és szubjektív mutatók alapján. Objektív mutató piacképes tudás és a munkához nélkülözhetetlen kompetenciák minősége is. Míg szubjektív mutató lehet az egyén kompetenciaérzése. Ennek megfelelően eredményesnek tekinthető az a 
hallgató, aki a követelményeket időben tudja teljesíteni és fejlődése nyomon követhető (Pusztai, 2011; Török, 2016). Egyes megközelítések az eredményesség szempontjából fontosnak tartják a tanulmányi átlagot, a kreditek számát, és a tanulmányok melletti kitartást (Astin, 1993; Pascarella \& Terezini, 2005), míg mások a képességek és kompetenciák fejlődését tartják fontos mutatónak (Pike \& Kuh, 2005). Török et al. (2016) szerint, ha figyelembe vesszük az alábbi megközelítéseket, akkor azokat a hallgatókat tekinthetjük eredményesnek, akik piacképes szaktudással, megfelelő kompetenciákkal rendelkeznek, s a megszerzett tudását kamatoztatni tudják a munkaerőpiacon.

A hallgatók 56\%-ának szubjektív megítélése szerint a képzés által sokkal eredményesebbek lettek az egyetemen, azonban 23\%-uk úgy érezte, hogy inkább a gyakorlati helyen vannak sikerei, mintsem az egyetemen. A megkérdezettek $14 \%$-a szerint nehezebben tud a tanulásra koncentrálni, mióta duális képzésben vesznek részt. Török (2017) vizsgálata szerint a duális képzésben lévő hallgatókra kevésbé jellemző a tanulmányok halogatása vagy a lemorzsolódás. A kutatási eredményeink szerint lemorzsolódás tekintetében nincs számottevő különbség a duális és nem duális képzésben résztvevő hallgatók között, a hallgatók alig 8\%-a szakította meg a tanulmányait. Zimányi (2016) kutatása szerint - amelyben a Budapesti Gazdasági Egyetem hallgatóit vizsgálta- a duális képzésben tanulók körében nincs képzésből kilépő hallgató, azonban az eredményeink közelítenek az EUROSTUDENT VI. átlagához, amely szerint a felsőoktatásban töltött évek során az egyetemisták 7\%-a különböző okokból ugyan, de megszakítja a tanulmányait. Zimányi (2016) kutatása arra világított rá, hogy a képzés legnagyobb hátránya a vizsgaidőszak túlterheltsége, mégis a duális képzésben lévő hallgatók motiváltabbak, és eredményesebbek. A kvantitatív kutatásunk során a hallgatók 31\%-a válaszolta azt, hogy a duális képzés miatt sokkal eredményesebbek, mint a hagyományos képzésben lévő társaik, 28\%-uk vallotta azt, hogy valamilyen területen sikeresebbnek érzik magukat.

A duális képzésben lévő hallgatók eredményességét az utóbbi két féléves tanulmányi átlaguk is bizonyítja. Az elemzés során átlag alatti és átlag feletti tanulmányi eredményeket különböztettünk meg.

2. ábra: A hallgatók eredményessége az őszi* és tavaszi félév átlagai alapján ( $N=229$ )

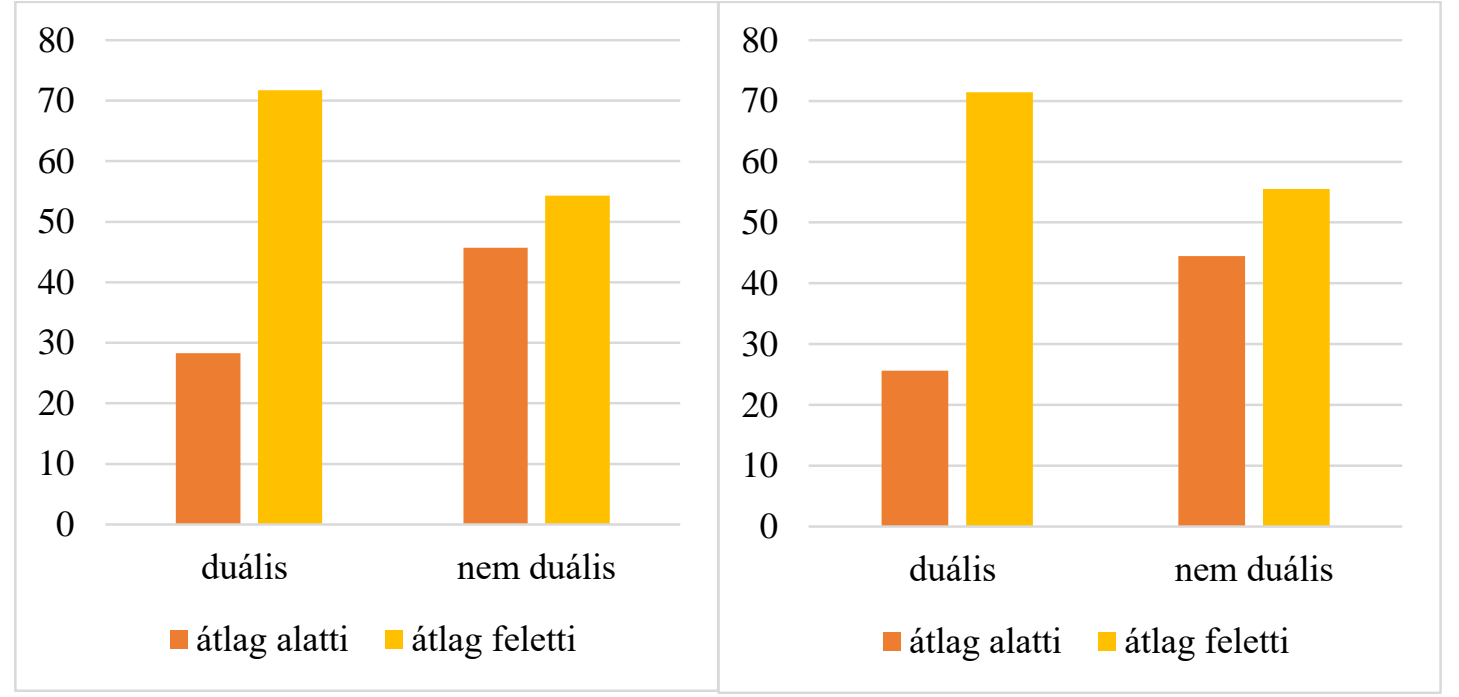

Forrás: saját szerkesztés

Láthatjuk, hogy az őszi félévben a duális képzésben lévő hallgatók 71\%-a átlag feletti tanulmányi eredménnyel rendelkezik, míg a nem duális képzésben tanulóknak csak az 54\%-a. A tavaszi félévben nem történt jelentősebb változás, mindkét vizsgált félévben a duális képzésben tanulók szignifikáns előnye tapasztalható. A tanulmányi átlagokból kifolyólag nem meglepő, hogy a duális képzésben lévők 55\%-a részesül tanulmányi ösztöndíjban, de a megkérdezettek alacsony százalékára jellemző a kutatócsoportban való részvétel, vagy valamilyen tudományos pályamú elkészítése. A duális képzéses hallgatók $8 \%$-a rendelkezik valamilyen önálló programmal/alkotással, valamint magasabb arányban 
rendelkeznek középfokú és felsőfokú nyelvvizsgával. A logisztikus regresszió és az általunk mért eredményességi mutató alapján a duális képzésben résztvevő hallgatók esetében szignifikánsan nagyobb az esély, hogy jobb tanulmányi eredményeik vannak, mint a hagyományos képzésben tanuló társaiknak $(p=0,005)$. Továbbá a duális képzésben résztvevők $80 \%$-a biztosan abban, hogy a szakmájában fog elhelyezkedni, azonban képzési formától függetlenül mindkét hallgatói csoportban a végzettség megszerzése utána a munkaerőpiacon való elhelyezkedés a cél. A duális hallgatók $12 \%$-a a jelenlegi munkahelyén szeretne elhelyezkedni, de a megkérdezettek csaknem ötödét a továbbtanulás is foglalkoztatja. Eredményeik párhuzamot mutatnak Török \& Kovács (2015) korábbi eredményeivel, amely szerint a duális hallgatók elsődleges célja a munkaerőpiacon való elhelyezkedés, ezt követően pedig a továbbtanulás. Török \& Kovács (2015) szerint a duális képzésben lévő hallgatók magasabb szintre kívánják emelni a tudásukat, s ezért szerepel a jövőbeli céljaik között a mesterképzésre való jelentkezés, továbbá Holik \& Pogátsnik (2016) szerint a duális hallgatók határozottabb jövőképpel rendelkeznek, s pozitívabban ítélik meg mind az elméleti, mind a gyakorlati képzésüket.

A kvantitatív kutatásunk eredményei megerősítették, hogy a duális képzés eredményességre gyakorolt hatása jelentős. A duális hallgatók sikeressége az általunk használt objektív és szubjektív mutatók mentén is megmutatkozott, mind tanulmányi átlagukban, mind az önreflexiójuk alapján. A kutatás kvalitatív szakaszában a duális hallgatók fejlődésére és sikerességének percepcióira összpontosítottunk.

\section{A hallgatók fejlődése a partnervállalatok és saját megítélésük alapján}

A kutatás ezen szakaszában hallgatókkal $(n=10)$, valamint a partnervállalatok munkatársaival $(n=11)$ készítettünk félig strukturált interjúkat. A kvalitatív kutatás során az együttmúködés, a képzéssel való elégedettség valamint a gyakorlati oktatás felépítése mellett arra is fókuszáltunk, hogyan a megkérdezettek miben látják a hallgatók fejlődését.

Habár a hallgatói munkavállalás alatt az egyetemisták által végzett tipikus diákmunkákat, és olyan tanulmányaikhoz kapcsolódó munkákat értünk, amelyekre a diákok önállóan, vagy diákszövetkezet, karrieriroda révén jelentkeznek, mégsem vonatkoztathatunk el a duális képzés eredményességre gyakorolt hatása során olyan hallgatói munkavállalással kapcsolatos kutatásoktól, amelyek szerint a munkahely tulajdonképpen egy tanulási helyszín. Perna (2010) szerint a munkavégzésnek identitásképző szerepe van, s pozitívan hat a tanulmányi teljesítményre, és az elköteleződésre. Egyes kutatások arra hívják fel a figyelmet a horizontális illeszkedés pozitívan befolyásolja a hallgatók eredményességét, ami egybevág korábbi kutatások eredményeivel (Geel al., 2012; Gáti \& Róbert 2013). A képzési területhez kapcsolódó, de intenzív óraszámú munkavégzés további pozitív hatásokkal jár, amely nem csak az eredményességre, de a későbbi elhelyezkedésre is kedvezően hat (Di Paolo \& Matano, 2016).

A munkavállalás pozitívan hat a különböző soft skillekre (Beerkens, 2011; Pollard et al. 2013; SanchezGelabert et al., 2017), hozzájárult a hallgatók kommunikációs készségének, problémamegoldásának és a time-management fejlődéséhez (Neil et al. 2004; Pusztai \& Kocsis 2019). Török et al. (2014) szerint a hazánkban is megnőtt - kimondottan a mérnökképzésben - a szakmailag kifogástalan pályakezdők iránti igény, akik nem csak megfelelő szaktudással, hanem különböző soft skill-ekkel is rendelkeznek. Az előzőekben említett kompetenciák mellett még kiemeli az idegen nyelv ismeretét, a tárgyalási technika meglétét valamint a prezentációk bemutatásához szükséges készségeket. A kvalitatív kutatás során tapasztaltak alátámasztották, hogy a duális képzésben részt vevő hallgatók előrehaladása a szakmai tapasztalatok megszerzése mellett a különböző soft skill-ek fejlődésében érthető tetten.

„Sokat fejlödött a precizitásom, és egyre helyesebben, bátrabban használom a szaknyelvet." (müszaki menedzser hallgató)

„A duális képzésben lévő hallgatóink egyre többet fejlődnek. Színesednek az előadásaik, meg mernek szólalni... az elején nem nagyon hallottam a hangjukat. Az első félév után látni rajtuk, hogy egyre jobban kommunikálnak, magabiztosabbak, beilleszkednek a csapatba. Van olyan hallgató, aki az elején még a müszaki rajzot is alig látott, most pedig saját projektje van." (mentor) 
További hallgatói munkavállalással foglalkozó kutatások arra világítottak rá, hogy a munkavégzés során a diákok munkaérték preferenciája is alakulnak, valamint általános és úgynevezett átruházható készségekre tesznek szert (Buscha et al., 2012; Rothstein, 2007; Staff \& Mortimer, 2007). Ebből kifolyólag a duális hallgatókkal és a partnervállalatokkal folytatott kvalitatív kutatás során nemcsak a soft skill-ek fejlődésére koncentráltunk, hanem olyan képességek, készségek megszerzésére, amelyek a hétköznapi életben is szükségszerűek.

„Az iskolapadban megpróbálod megtanulni a dolgokat, de nincsen gyakorlati háttértartalom. S ilyenkor napi szinten szembesülök olyan dolgokkal, ami a hétköznapi élethez szükséges, meg ami egy munkavégzéshez szükséges. Mondhatom azt, hogy itt többet tanulok két nap alatt, mint egész félévbe az iskolapadban." (környezetmérnök hallgató1)

„Valamilyen szinten felkészített a későbbi dolgozó életre, hogyan osszam be az időmet, hogyan vállaljak felelösséget...ha valamit megígértem, hogy megcsinálok, akkor meg kell csinálnom, hiszen nem hátráltathatom a kollégáimat." (gépészmérnök hallgató)

„A szociális készségeket emelném ki, amire az egyetem keretein belül nincs sok lehetöségünk csapatban dolgozni. Itt szinte rákényszerül az ember, hogy együtt dolgozzon másokkal, hogy rugalmas legyen, hogy alkalmazkodjon a kollégákhoz, de ha úgy alakul, akkor önállóan is képes legyen dolgozni." (környezetmérnök hallgató2)

Pollard et al. (2013) dolgozó egyetemistákat vizsgáló kutatásában a diákok többsége hangsúlyozta a munka társadalmi aspektusának fontosságát, illetve kiemelték, hogy a munkavállalás az egyetemi környezettől eltérő, más társadalmi kapcsolatok kibontakozását tette lehetővé. A hallgatók visszajelzéseiből azt a következtetést vonta le, hogy a diákok a munka révén betekintést nyertek a gazdasági folyamatokba, valamint a munka lehetőséget adott arra, hogy felkészüljenek az egyetem utáni életre (Beerkens, 2011, Pollard et al. 2013).

„A korábbi munkahelyeimen nem volt ilyen jó csapat, mint itt, szóval ez egy pozitív csalódás volt nekem... Egy szuper, fiatalos csapat tagja vagyok." (logisztikai menedzsment hallgató)

A munkavállalás során a hallgatók kapcsolati tôkéje is gyarapszik, ugyanis a munkájuk révén lehetőségük volt találkozni különféle emberekkel, így a kapcsolati tőke gyarapítása jelentős lehet a későbbi karrier során. Szőcs és Hamvas (2015) szerint a tanulás melletti fizetett munka - függetlenül attól, hogy kapcsolódik-e a tanulmányok jellegéhez - mindhárom tőkefajtát gyarapítja: nő a gazdasági tőke, hiszen jövedelmet szerez, nő a kulturális tőke, ugyanis a munkavállalás során fejlődnek a munkaerő-piaci skillek, és kapcsolati tőke is gyarapszik. A megszerzett tőkék segíthetnek a jobb állás megtalálásában. Bourdieu elméletének vonatkozásában a tanulás melletti fizetett munkák által szerzett kapcsolati (network) és kulturális tőkét (munkaerőpiaci skillek, szakmai ismeretek) a diákok később egy jobb állás elnyerésével gazdasági tőkévé konvertálhatják.

A partnervállalatok munkatársaival és a mentorokkal készített interjúk alapján elmondható, hogy a megkérdezettek szerint a képzés ideje alatt a duális hallgatók különösen sokat fejlődnek a munkahelyi szocializációban. A munkatársakhoz való alkalmazkodás, a velük folytatott kommunikáció írott és íratlan szabályai azok a tényezők, amelyeket a fiatalok nem tudnak az egyetem falain belül elsajátítani, így a gyakorlati helyen szerzett tapasztalatnak különösen nagy szerepet tulajdoníthatunk.

„Egyrészt szereznek munkatapasztalatot, másrészt integrálódnak egy szervezetbe, ami fiatalon talán ijesztő is lehet, de ha elég nyitott a szervezet is, akkor nincs gond. Ezeknek a srácoknak maximum diákunka tapasztalata lehet, szakmai nem, szerintem ezért is nagyon jó a duális képzés." (mentor)

„A fiataloknál alapvető kompetenciák hiányoznak. Amikor elöször bejött hozzám egy elsőéves...úgymond szocializálni, nevelni kellett öket. Merj köszönni, merj kérdezni." (mentor) 
„Egy bizonyos idő után a hallgatóinknak már nem csak önálló feladataik vannak, hanem minden feladatba be tudjuk öket vonni, mert a hallgatóink átlátják a céget, a feladatainkat, a folyamatokat, és ez nagyon fontos. " (mentor)

A hallgatók a munka révén szocializálódnak a munka világába, egy vállalati kultúrába, ugyanis a hallgatók megtanulnak kommunikálni az idősebb kollégákkal, a vezetőkkel, ügyfelekkel és munkatársaikkal. A munkavállalóknak be kell illeszkedniük a csapatba, ahhoz, hogy hatékonyan dolgozzon. A munkahelyi szocializáció lényege, hogy a hatékony munkavégzés által az egyén megtanul együtt dolgozni a munkatársaival, s javul a kapcsolatuk minősége. Pogántsnik (2019b) szerint a duális képzés számos lehetőséget nyújt a hallgatóknak, ilyen a vállalati és munkakultúra terén szerzett jártasság valamint a munkavégzési hatékonyság.

Ahogy már korábban említettük a hallgatói sikeresség kifejezhető a tanulmányok melletti elkötelezettséggel (Astin, 1993; Pascarella és Terezini, 2005, Pusztai, 2014), a megszerzett kompetenciákkal (Pusztai, 2011). Továbbá Török et al. (2016) szerint a személyes és szakmai fejlődést elősegíti, ha a hallgató számára a képzés kihívást jelent, s megélheti a kompetenciái fejlődését. A hallgatói munkavállalás foglalkozó kutatása szerint a munkavégzés növelheti a pálya iránti elkötelezettséget, és arra sarkalhatja a diákokat, hogy minél jobban teljesítsenek a tanulmányaik során, hogy elérjék a kitűzött és vágyott karriert (Rothstein, 2007).

„Eleve egy nagyon motivált hallgató volt, és jó személyiségű emberke, sezt bizonyítja az is, hogy az egy év alatt elérte azt is, hogy ösztöndíjban részesítsük. A gyakorlati készségek fejlödtek leginkább, ami eddig nem volt neki. Többek között ennek is köszönheti ezt az ösztöndij lehetöséget." (mentor)

Pap-Szigeti et al. (2018) kutatása arra mutatott rá, hogy a duális hallgatók az önreflexió erősségében, és annak realitásában kedvezőbb képet mutat a hallgatótársaikhoz képest. A hallgatók körében végzett kvalitatív kutatás során igyekeztük feltárni, hogy a diákok a saját megítélésük alapján, hogyan látják magukat a hagyományos képzésben résztvevő társaikhoz viszonyítva. Az egyetemistákkal készített interjúk általános tapasztalata, hogy a csoporttársaikhoz viszonyítva duális hallgatók eredményesebbnek érzik magukat, amelyet azzal támasztottak alá, hogy az egyetemi órákon jobban teljesítenek, valamint társaikkal ellentétben gyakrabban vállalnak plusz feladatokat, mint a tudományos diákköri részvétel, nyelvvizsga, konferencia.

„Én ebben egészen biztos vagyok, hogy érezhető közöttünk a különbség, még ha egyelöre nem is olyan élesen, de szerintem az idő elörehaladtával az egyre érezhetöbb lesz. Mivel nekünk ez óriási plusz, hogy látjuk azt, hogy amit tanulunk azt, hogyan tudjuk a gyakorlatban hasznositani, s az, hogy ők ezt hátránynak érzik e majd, vagy nem... De lett volna elég szabad hely, ha valaki a duális képzést választja. Nekem is van olyan csoporttársam, akik kerekperc megmondta, hogy a saját korlátait feszegetné ezzel, és neki nem férne bele, hogy egyszerre egyetemre jár, s mellette dolgozna is." (környezetmérnök hallgató1)

„A szakdolgozatomra azt mondta az oktató, hogy nagyon jó, színvonalas és indulni kellene a Tudományos Diákköri Konferencián, ugyanis a gyakorlati helyemen kifejlesztettünk egy beszállító értékelö rendszert. Második helyezett lettem és indulhattam az országos versenyen is." (müszaki menedzser hallgató)

„Sokkal eredményesebbnek érzem magam. Én hetente 3 napot töltök a gyakorlati helyen, és dolgozok, mégis azt látom, hogy ök sokkal kevesebbet energiát fektetnek a tanulmányaikba, mint én. Sokszor dolgozunk csoportokban, és ott is én dolgozom többet, ugyanis a végén kiderül, hogy ök nem tudtak úgy haladni, hiába nem dolgoznak." (müszaki menedzser hallgató)

A duális hallgatókkal készített interjúkból arra következtethetünk, hogy a diákok olyan előnyökre tesznek szert a képzés során, amely az egyetemi pályafutásukat pozitívan befolyásolja. Pap-Szigeti et al., (2018) szerint a hallgatók kompetenciáiban, fejlődésében megmutatkozó különbségek a 
hagyományos képzésben lévő hallgatók hátrányaként jelentkezhet, így kiemelten fontos az egyetemi képzések során a készségek fejlesztése.

\section{Összegzés}

A munkaerőpiaci igények változása miatt a felsőoktatási intézmények fontos feladata, hogy a gazdaság elvárásainak megfelelő munkaerőt képezzen. Számos kutatás szerint napjainkban a kompetenciák fejlesztésének igénye került a figyelem középpontjában. A kompetenciák közül a nem kognitív tényezők is hozzájárulnak ahhoz, hogy a végzettek potenciális munkaerővé váljanak. Ilyen kompetencia lehet a kritikus gondolkodás, az együttmúködés, a tárgyalási technika vagy egyéb soft skill-ek. Korábbi kutatások mutattak rá arra, hogy a munka alapú tanulás hozzájárul az említett képessége, kompetenciák fejlesztéséhez, amelynek fontos eleme a munkahelyi környezetben való részvétel. $A$ jelenlegi kutatásunkban azt vizsgáltuk, hogy a duális képzés hogyan támogatja a hallgatók fejlődését. A kérdésre kvantitatív és kvalitatív kutatási módszerekkel igyekeztünk válaszolni. A kvantitatív eredményeink szerint a duális képzésben lévő hallgatók sikeresebbek, mint a hagyományos képzésben tanuló társaik. Az objektív mutatók mellett szubjektív vélemények támasztották alá a duális hallgatók eredményességét, $s$ ezáltal a hipotézisünk is bizonyítást nyert. A kvalitatív vizsgálati szakaszban hallgatókkal és a partnervállalatok munkatársaival készítettünk interjúkat, amelynek eredményei megerősítették a korábbi kutatásokban tapasztaltakat, miszerint a duális képzés hozzájárul nem csak a tanulmányi sikerességhez, hanem a különböző soft skill-ek fejlődéséhez is. Korábbi hallgatói munkavállalás kapcsolatos kutatások is bizonyították, hogy a tanulmányi területen végzett munka pozitív irányba befolyásolja a hallgatók egyetemi pályafutását. Azok a hallgatók, akik a tanulmányi területükhöz szorosan kapcsolódó munkakörben dolgoznak, fontosnak tartják a tanulmányaik során szerzett kompetenciák alkalmazzák, kamatoztassák. A diákok úgy vélik, hogy ezeket a készségeket a munkáltatók értékelik, és olyan hasznosnak, sőt akár döntő fontosságúak is lehetnek, amelyeket egy állásinterjú során kiemelhetnek. A kutatási eredményeik számos korábbi kutatással megegyezően arra világít rá, hogy a duális képzésben szerzett tapasztalatok hozzájárulnak a hallgatók eredményességéhez, és fejlődéséhez. A kvalitatív eredményeink arra mutattak rá, hogy a támogató mentor, munkatárs iránymutatása olyan tényező, amely tovább fokozza a hallgatók sikerességét. Véleményünk szerint egy útmutató oktatónak vagy mentornak fontos szerepe lehet az egyetem falain belül is, ugyanis korábbi vizsgálatok is megállapították, hogy a hallgatók eredményességét fokozza, ha megfelelő kapcsolatot ápolnak intézményi környezetükkel (Pusztai, 2011). Emellett a kutatásunk rávilágít a gyakorlati képzés fontosságára, hogy milyen motiváló erővel bír a gyakorlati tudás megszerzésének lehetősége. Eredményeink arra ösztönöznek, hogy felmérést longitudinális kutatássá fejlesszük, ugyanis ez lehetővé tenné, hogy hosszabb távon kövessük nyomon a duális képzésben résztvevő hallgatók eredményességét és fejlődését.

\section{Felhasznált szakirodalom}

- Astin, A. W. (1993): What matters in college? Four critical years revisited. Jossey-Bass Publishers, San Francisco, CA.

- Autor, D. H. - Levy, F. - Murnane, R. J. (2003): The Skill Content of Recent Technological Change: An Empirical Exploration. The Quarterly Journal of Economics, 118, 4, pp. 1279-1333. https://economics.mit.edu/files/11574.

- Baethge, M. \& Wolter, A. (2015). The German skill formation model in transition: from dual system of VET to higher education? Journal for Labour Market Research, 48(2), pp. 97-112.

- Beerkens, M., Mägi, E. \& Lill, L. (2011): University studies as a side job. Causes and consequences of massive student employment in Estonia. Higher Education, 61(6), pp. 679692. DOI: 10.1007/s10734-0109356-0. 
- Buscha, F., Maurel, A., Page, L., \& Speckesser, S. (2012): The effect of employment while in high school on educational attainment: A conditional difference-in-differences approach. Oxford Bulletin of Economics and Statistics, 74(3), pp. 380-396.

- Castro, C. M. \& Levy, C. D. (2001): Four Functions in Higher Education. DOI: https://doi.org/10.6017/ihe.2001.23.6594

- Deming, D. J. (2015): The Growing Importance of Social Skills in the Labor Market. (NBER Working Paper Series, 21473). http://www.nber.org/papers/w21473

- Derényi, A. (2010): A felsőoktatás és a foglalkoztathatóság kapcsolatának értelmezései. Educatio, 2010/3. 361-369. o.

- Di Paolo, A. \& Matano, A. (2016): The Impact of Working while Studying on the Academic and Labour Market Performance of Graduates: the Joint Role of Work Intensity and Job-Field Match. https://www.aiel.it/cms/cms-files/submission/all20160608164320.pdf.

- Donald, W. E., J. A. Melanie \& Y. Baruch (2018): Students' perceptions of education and employability: Facilitating career transition from higher education into the labor market. Career Development International. ISSN: 1362-0436

- ECLAC / ILO (2017): Employment Situation in Latin America and the Caribbean. The transition of young people from school to the labour market.

- Fazekas, K. (2018): Nem-kognitív készségek hiánya a munkaerőpiacon. Non-cognitive skill shortage in labour market. Magyar Tudomány 179, 1., 24-36. o. DOI: 10.1556/2065.179.2018.1.3.

- Gáti, A. \& Róbert, P. (2011): Munkavállalás a tanulás mellett: kényszerüség vagy befektetés? In: Garai O. és Veroszta Zs. (szerk.), Frissdiplomások (93-111). Budapest: Educatio Társadalmi Szolgáltató Nonprofit Kft.

- Geel, R. \& Backes-Gellner, U. (2012): Earning While learning. When and How Student Employment is Beneficial. Labour, 26(3), pp. 313-340.

- Göhringer, A. (2002): University of Cooperative Education - Karlsruhe: The Dual System of Higher Education in Germany. http://www.apjce.org/volume 3/volume 3253 58.pdf

- Grosemans I., Coertjens L. \& Kyndt, E. (2017): Exploring learning and fit in the transition from higher education to the labour market: A systematic review. Educational Research Review, 21. pp. 67-84.

- Heckman, J. J., Humphries, J. E. \& Kautz, T. (2014): The Myth of Achievement Tests: The GED and the Role of Character in American Life. Chicago: University of Chicago Press.

- Heinz, W. R. (2009): Structure and agency in transition research. Journal of Education and Work, 5, 391-404.http://doi.org/c2p8sx.

- Holik, I. \& Pogátsnik, M. (2016): A duális képzés bevezetésének első tapasztalatai mérnök informatikus szakos hallgatók tanulmányi eredményességének és véleményének tükrében. In: Zsolnai, Anikó; Kasik, László (szerk.). A tanulás és nevelés interdiszciplináris megközelítése: XVI. Országos Neveléstudományi Konferencia: Program és absztraktkötet. Szeged, Magyarország: MTA Pedagógiai Bizottság, SZTE BTK Neveléstudományi Intézet.

- Kiss, Zs. (2016): Fiatal diplomások foglalkoztathatósága Magyarországon. Doktori (PhD) értekezés.

- Khine, M.S. \& Areepattamannil, S. (2016): Non-cognitive Skills and Factors in Educational Attainment. Rotterdam, Sense Publishers, pp. 443.

- Kivinen, O. \& Nurmi, J. (2003): Unifying Higher Education for Different Kinds of Europeans. Higher Education and Work: A comparison of ten countries. Comparative Education 39(1). DOI: 10.1080/03050060302563 
- Kocsis Zs. (2018): Melyik út vezet a sikerhez? Hallgatói visszajelzések a munkatapasztalataikról és a duális képzésről. In: Tóth P., Simonics I., Manojlovic H. \& Duchon J. (szerk.): Új kihívások és pedagógiai innovációk a szakképzésben és a felsőoktatásban. 437-452. o.

- Kovács, Zs \& Török (2016): Duális képzés - az együttmúködésen alapuló képzési forma. In: Fodorné Dr. Tóth K. (szerk). Felsőoktatási Kihivások. Alkalmazkodás stratégiai partnerségben. Pécs: MELLEARN. 209-2016. o.

- Kovács, Zs. \& Török E. (2016): Dual System for Renewing Hungarian Higher Education. International Journal of Education and Learning Systems.

https://www.researchgate.net/publication/299398253 Dual System for Renewing Hungar ian Higher Education.

- Neill, N., Mulholland, G., Ross, V., Leckey, J. (2004): The influence of part-time work on student placement. Journal of Further and Higher Eduction. doi:10.1080/0309877042000206705.

- Pap-Szigeti R., Török E. \& Tánczikné Varga Sz. (2018): Kérdőívek és tesztek elektronikus felvételét támogató szoftver fejlesztése és alkalmazása. In: Fodorné Dr. Tóth Krisztina (szerk). A felsőoktatási lifelong learning társadalmi és gazdasági haszna: kutatás - fejlesztés - innováció. Pécs: MELLEARN. 21-30. o.

- Pascarella, E. T. \& Terezeni, P. T. (2005): How college affects students: Vol. 2. A third decade of research. Jossey-Bass Publishers, San Francisco, CA.

- Perna, L. (2010): Understanding the Working College Student New Research and Its Implications for Policy and Practice" Sterling: Stylus Publishers.

- Pike, G. R. \& Kuh, G. D. (2005): First- and Second-Generation College Students: A Comparison of Their Engagement and Intellectual Development. Journal of Higher Education, 76(3), pp. 276-300.

- Pogátsnik, M. (2018): Dual Education: The Win-Win Model of Collaboration between Universities and Industry. International Journal Of Engineering Pedagogy, 8(3), pp. 145-152.

- Pogátsnik, M. (2019a): The Impact of Dual Higher Education on the Development of NonCognitive Skills. In: G. Kováts, Z. Rónay (eds.) In search of excellence in higher education. Budapest, Magyarország, pp. 179-190.

- Pogátsnik M. (2019b): A munka alapú tanulás hatása a nem kognitív készségek fejlődésére a mérnökképzésben. In: Juhász E. \& Endrődy O. (szerk.). Oktatás - Gazdaság - Társadalom. HERA Évkönyvek VI. Budapest: Magyar Nevelés- és Oktatáskutatók Egyesülete. 151-167. o.

- Pollard, E., Williams, M., Arthur S. \& Mehul Kotecha, M. (2013): Working while Studying: a Follow-up to the Student Income and Expenditure Survey 2011/12.

- Pusztai G. (2011): A láthatatlan kéztöl a baráti kezekig. Hallgatói értelmezői közösségek a felsőoktatásban. Új Mandátum Könyvkiadó, Budapest.

- Pusztai, G. (2013). A felsőoktatás munkára felkészítő szerepe a hallgatók értelmezésében. In: Kun A., Polónyi I. (szerk.), Az Észak-Alföldi régió helyzete: Képzés és munkaerőpiac. Új Mandátum Kiadó, Budapest. 9-29. o.

- Pusztai G. (2013): The Effects of Institutional Social Capital on Students' Success in Higher Education Abstract. Hungarian Educational Research Journal (HERJ), 3., 1-13.

- Pusztai, G. \& Kocsis, Zs. (2019): Combining and Balancing Work and Study on the Eastern Border of Europe. Social Sciences, 8(6).

- Rostan, M.\& Stan, A. (2017): Italian graduates' employability in times of economic crisis: overview, problems and possible solutions. Sociológicó Série, II., pp. 37-52. http://journals.openedition.org/sociologico/1818.

- Rothstein, D. S. (2007): High school employment and youths' academic achievement. Journal of Human Resources, 42(1), pp. 194-213. 
- Sági, M. (2011): Pályakezdő diplomások munkába állási stratégiái. In: Garai O. és Veroszta Zs. (szerk.) Frissdiplomások (93-111). Budapest: Educatio Társadalmi Szolgáltató Nonprofit Kft.

- Sanchez-Gelabert, A., Figueroa, M., Elias, M. (2017): Working whilst studying in higher education. The impact of the economic crisis on academic and labour market success. European Journal of Education, 52 (2), S. pp. 232-245. DOI: 10.1111/ejed.12212

- Staff, J., \& Mortimer, J. T. (2007): Educational and work strategies from adolescence to early adulthood: Consequences for educational attainment. Social Forces, 85(3), pp. 1169-1194.

- Szabó, Cs. (1998). Diplomások elhelyezkedési esélyei. Educatio, 1998/III., 599-606 o.

- Szőcs, A. \& Hamvas, L. (2015): Alternatives of how to prepare for the future labor market. Metszetek, 4(4), 146-160. o.

- Teichler, U. (2002): Graduate employment and work in Europe: diverse situations and common perceptions. Tertiary Education and Management, 8(3), 199-216. o.

- Teichler, U. (2003): Az európai felsőoktatási reformok föbb kérdései. Egy felsőoktatás-kutató véleménye. Educatio, 12(1), 3-18. o.

- Teichler, U. (2011): International Dimensions of Higher Education and Graduate Employment. Chapter frombook The Flexible Professional in the Knowledge Society: New Challenges for Higher Education, pp. 177-197.

https://www.researchgate.net/publication/226326374 International Dimensions of Higher Education and Graduate Employment

- Török E., Pap-Szigeti R., Ailer P. \& Palkovics L.(2014). A Kecskeméti Főiskola duális képzésének monitoring vizsgálata a hallgatók visszajelzései alapján. A jövő jármúve, 1-2, 32-36. o.

- Török E. \& Kovács Zs. (2015). Future-oriented Practice in Higher Education. In: Recent Research in Engineering Education, Proceedings of the 11th International Conference on Engineering Education, Salerno, Italy, Published by WSEAS Press. ISBN: 978-1-61804-312-2

- Török E., Brindza A., Hercz M., Koltói L., Pap-Szigeti R. \& Rigó R. (2016). TALENTUM: hallgatói sikerességet támogató és tanulást segítő pilot program a Kecskeméti Főiskolán. In: Fodorné Dr. Tóth K. (szerk). Felsőoktatási Kihívások. Alkalmazkodás stratégiai partnerségben. Pécs: MELLEARN. 87-97. 0.

- Török E. (2017). A duális képzés felsőoktatásban betöltött innovációs szerepe. In: Fodorné Dr. Tóth Krisztina. Felsőoktatás, életen át tartó tanulás és az ENSZ fenntartható fejlesztési célok megvalósítása. Pécs: MELLEARN. 187-198. o.

- Vysotskaya, (2017). Youth transition to the labour market during employment mobility. Employment and inequality of young people in Europa. Tér és Társadalom, 31(4).

- Setényi, J. (2011). Duális képzés a felsőoktatásban? http://oktpolcafe.hu/dualis-kepzesafelsooktatasban-602/.

- Simonics, I (2015): Seminar organization, planning and management. In: P. Tóth, P. (eds.): Theoretical foundations of corporate mentor training. Óbuda University, Budapest, pp. 53-73.

- Zimányi, K. (2016). Duális képzés a gazdaságtudományi képzési területen, a BGE tapasztalatai. In: Fodorné Dr. Tóth Krisztina. Felsőoktatás, életen át tartó tanulás és az ENSZ fenntartható fejlesztési célok megvalósítása. Pécs: MELLEARN. 97-105. o. 